OPEN ACCESS

Edited by:

James Lloyd

Stellenbosch University, South Africa

Reviewed by:

Biswapriya Biswavas Misra, University of Florida, USA

Taras P. Pasternak,

University of Freiburg, Germany

*Correspondence:

Sandhya Mishra smishra@csmcri.org;

Arup Ghosh

arupghosh@csmcri.org

Specialty section

This article was submitted to

Plant Biotechnology,

a section of the journal

Frontiers in Plant Science

Received: 01 August 2015 Accepted: 28 December 2015 Published: 20 January 2016

Citation:

Maurya R, Chokshi K, Ghosh T,

Trivedi K, Pancha I, Kubavat D, Mishra S and Ghosh A (2016) Lipid Extracted Microalgal Biomass Residue as a Fertilizer Substitute for Zea mays

L. Front. Plant Sci. 6:1266

doi: 10.3389/fpls.2015.01266

\section{Lipid Extracted Microalgal Biomass Residue as a Fertilizer Substitute for Zea mays L.}

\author{
Rahulkumar Maurya ${ }^{1,2}$, Kaumeel Chokshi ${ }^{1,2}$, Tonmoy Ghosh ${ }^{1,2}$, Khanjan Trivedi ${ }^{2,3}$, \\ Imran Pancha ${ }^{1,2}$, Denish Kubavat ${ }^{2,3}$, Sandhya Mishra ${ }^{1,2 *}$ and Arup Ghosh ${ }^{2,3 *}$ \\ ${ }^{1}$ Salt and Marine Chemicals Division, CSIR-Central Salt and Marine Chemicals Research Institute, Bhavnagar, India, \\ ${ }^{2}$ Academy of Scientific and Innovative Research, CSIR-Central Salt and Marine Chemicals Research Institute, Bhavnagar, \\ India, ${ }^{3}$ Wasteland Research Division, CSIR-Central Salt and Marine Chemicals Research Institute, Bhavnagar, India
}

High volumes of lipid extracted microalgal biomass residues (LMBRs) are expected to be produced upon commencement of biodiesel production on a large scale, thus necessitating its value addition for sustainable development. LMBRs of Chlorella variabilis and Lyngbya majuscula were employed to substitute the nitrogen content of recommended rate of fertilizer (RRF) for Zea mays $L$. The pot experiment comprised of 10 treatments, i.e., T1 (No fertilizer); T2 (RRF-120 N: $60 \mathrm{P}_{2} \mathrm{O}_{5}: 40 \mathrm{~K}_{2} \mathrm{O} \mathrm{kg} \mathrm{ha-1}$ ); T3 to $\mathrm{T} 6-100,75,50$, and $25 \% \mathrm{~N}$ through LMBR of the Chlorella sp., respectively; T7 to $T 10-100,75,50$, and $25 \% \mathrm{~N}$ through LMBR of Lyngbya sp., respectively. It was found that all LMBR substitution treatments were at par to RRF with respect to grain yield production. T10 gave the highest grain yield $\left(65.16 \mathrm{~g} \mathrm{plant}^{-1}\right)$, which was closely followed by that (63.48 $\mathrm{g} \mathrm{plant}^{-1}$ ) under T5. T10 also recorded the highest phosphorus and potassium contents in grains. T4 was markedly superior over control in terms of dry matter accumulation (DMA) as well as carbohydrate content, which was ascribed to higher pigment content and photosynthetic activity in leaves. Even though considerably lower DMA was obtained in Lyngbya treatments, which might have been due to the presence of some toxic factors, no reduction in grain yield was apparent. The length of the tassel was significantly higher in either of the LMBRs at any substitution rates over RRF, except T6 and T7. The ascorbate peroxidase activity decreased with decreasing dose of Chlorella LMBR, while all the Lyngbya LMBR treatments recorded lower activity, which were at par with each other. Among the Chlorella treatments, only T5 recorded significantly higher values of glutathione reductase activity over RRF, while the rest were at par. There were significant increases in carbohydrate and crude fat, respectively, only in T4 and T3 over RRF, while no change was observed in crude protein due to LMBR treatments. Apparently, there was no detrimental effect on soil properties, suggesting that both the LMBRs can be employed to reduce the usage of chemical fertilizers, thus promoting maize crop production in a sustainable manner.

Keywords: Chlorella, Lyngbya, fertilizer, de-oiled microalgae, maize, soil properties, photosynthesis 


\section{INTRODUCTION}

The effect of climate change due to the incessant burning of fossil fuels is now being felt across the globe (Ghosh, 2012) which has necessitated the search for alternate sources of cleaner energy (Ghosh et al., 2007; Ghosh, 2014). In the last few years, there has been intensive research on microalgae as it is an attractive feedstock for biofuel production (Chisti, 2007). Microalgae have been reported to have much higher primary productivity as compared to other terrestrial plants having biofuel potential (Mata et al., 2010). Processes for conversion of microalgal oil to biodiesel have already been developed (Mishra et al., 2012) and it is expected that once the microalgal cultivation technology is sufficiently optimized, adequate feedstock would be available from large scale cultivation for biofuel production. During algal biodiesel production, lipid is extracted from microalgal biomass through suitable solvent and converted to biodiesel through trans-esterification process. After lipid extraction, a huge amount of de-oiled microalgal biomass remains left.

Algae biomass is a complex material comprising of carbohydrates, lipids, proteins, and several potentially interesting molecules. The biofuel sector is specifically interested in carbohydrates (mainly C6) and lipids (mainly C16-C22), the amount of which could vary as a function of the algae species, strains, and the cultivation methods adopted (Chiaramonti et al., 2015). The current worldwide algae biomass production has been projected to be at more than 20,000 dry tons per year (Verdelho, 2013; Zittelli et al., 2013a,b; Chiaramonti et al., 2015). However, the algae market is expected to grow as the constraints of algal production are overcome and the cost of production is reduced. As per Studt (2010) and Rodolfi et al. (2009), the potential oil yield from microalgae on equal acreage basis is 5-20 times higher than that of oil from palm species. Assuming a conservative figure of $25 \%$ extractable oil from microalgal biomass (Chisti, 2007), for every metric ton of biodiesel manufactured, three times the amount of lipid extracted microalgal biomass residue (LMBR) will be produced. To make the biodiesel sustainable, it is also necessary to valorize such biomass for various applications, thus also offsetting the cost of biodiesel. Such value addition of LMBRs may be by its use as feed and fertilizer; fermentation to bio-methane and bio-ethanol; as a nutrient source for organisms; thermo-chemical conversion into various fuels and chemicals and as biosorbents for removal of dye and heavy metals from wastewater (Mata et al., 2010; Scott et al., 2010; Rashid et al., 2013; Maurya et al., 2014). Depending on the species, LMBRs are rich in protein and therefore rich in nitrogen content besides the presence of other essential plant macro- and micro-nutrients. Because of low carbon-nitrogen ratio, it cannot be utilized directly for bio-methane production, although such biomass can be utilized as animal feed, fertilizer, or nutrient source for organisms (Mata et al., 2010; Bryant et al., 2012; Gao et al., 2012). There are reports that shed light on the use of microalgae

Abbreviations: LMBR, lipid extracted microalgal biomass residues; RRF, recommended rate of fertilizer; CRD, completely randomized design; DMA, dry matter accumulation; APX, ascorbate peroxidase; GR, glutathione reductase; SSP, single super phosphate; MOP, muriate of potash; DAS, days after sowing; TVS, total volatile solid; DAP, di-ammonium phosphate; ROS, reactive oxygen species. as a potential source of nutrients and bioactive compounds that can be utilized for sustainable plant production either directly as an inoculum (Metting and Rayburn, 1983; Grzesik and Romanowska-Duda, 2014), as unprocessed dried algae (Mulbry et al., 2005), and sonicated biomass (Grzesik and Romanowska-Duda, 2015). However, no such studies have been reported yet that validate the use of LMBRs as a source of plant nutrients.

Urea, which is the most commonly used chemical nitrogenous fertilizers, is produced through very well-known Haber-Bosch process which rely on fossil fuels (Vance, 2001; Pfromm et al., 2011). Excessive use of chemical fertilizers is responsible for global warming, for example, assuming a recommended rate of 150:60:40 kg N: $\mathrm{P}_{2} \mathrm{O}_{5}: \mathrm{K}_{2} \mathrm{O}$ hectare ${ }^{-1}$ applied through urea, diammonium phosphate (DAP) and muriate of potash (MOP) for the cultivation of maize, $\sim 599 \mathrm{~kg} \mathrm{CO}_{2}$ equivalents are produced on account of fertilizer production and their transport (Singh et al., 2015). Using carbon rich residues as a chemical fertilizer substitute may also have other benefits such as improved soil health, stability of soil aggregates, soil water retention, carbon sequestration, and prevention of nutrient losses (Metting and Rayburn, 1983; Anand et al., 2015). Enhancing the productivity of crops in a sustainable manner without adversely affecting soil health should be the focus of the approaches to meet the increasing food demand (Singh et al., 2015).

In the present study, lipid-extracted biomass residues of two microalgal species, namely, Chlorella variabilis (ATCC PTA 12198) and Lyngbya majuscula have been evaluated for its nitrogen substitution potential for maize (Zea mays L.-a heavy feeder of nutrients) crop in a pot experiment. Different $\mathrm{N}$ substitution levels were used to evaluate their effects on crop growth, yield, quality, and soil properties.

\section{MATERIALS AND METHODOLOGY}

\section{LMBR Preparation and Characterization}

Initially, $1 \mathrm{~kg}$ biomass of each algae was taken for the lipid extraction. The lipid was extracted in soxhlet extractor using 3 $\mathrm{L} \mathrm{n}$-hexane per $\mathrm{kg}$ dry biomass. The extraction time of five cycles was $4 \mathrm{~h}$ in total. At the end of extraction, lipid, hexane, and deoiled biomass were recovered. The de-oiled biomass was sundried for a day and powdered by grinding in mixture grinder (Boss Cyclone B219, Boss Home Appliances, Mumbai, India). The chemical composition of Chlorella and Lyngbya LMBR has been presented in Table 1. TVS and ash were obtained by subjecting the ovendried biomass in a muffle furnace at $575 \pm 25^{\circ} \mathrm{C}$ (van Wychen and Laurens, 2013). Carbon, hydrogen, nitrogen and sulfur were analyzed using a CHNS analyzer (Perkin-Elmer Model 2 400, USA). Na and K was analyzed after wet ashing the LMBR samples with ternary acid mixture (Jackson, 1973), followed by their estimation using flame photometer (Toth et al., 1948); other micro and macro elements were analyzed by the X-Ray Fluorescence analyzer (Bruker AXS, S4 Pioneer, Billerica, Massachusetts, USA). Crude protein was calculated from nitrogen content using a multiplication factor of 6.25 (Jones, 1941). 
TABLE 1 | Composition of LMBRs from Chlorella and Lyngbya.

\begin{tabular}{lcc}
\hline Parameters & \multicolumn{2}{c}{ LMBR } \\
\cline { 2 - 3 } & Chlorella & Lyngbya \\
\hline TVS (\%) & $67.66 \pm 0.071$ & $55.82 \pm 2.58$ \\
Ash (\%) & $32.34 \pm 0.071$ & $40.73 \pm 1.57$ \\
Crude protein (\%) & $36.31 \pm 0.98$ & $24.75 \pm 0.28$ \\
C (\%) & $28.36 \pm 2.51$ & $23.40 \pm 1.56$ \\
H (\%) & $4.75 \pm 0.32$ & $4.42 \pm 0.28$ \\
N (\%) & $5.810 \pm 0.157$ & $3.960 \pm 0.045$ \\
S (\%) & $0.27 \pm 0.04$ & $0.43 \pm 0.03$ \\
P (\%) & $0.273 \pm 0.072$ & $0.097 \pm 0.004$ \\
K (\%) & $0.634 \pm 0.031$ & $0.579 \pm 0.044$ \\
Na (\%) & $1.466 \pm 0.016$ & $0.183 \pm 0.005$ \\
Ca (\%) & $0.017 \pm 0.002$ & $0.007 \pm 0.001$ \\
Mg (\%) & $0.07 \pm 0.01$ & $0.037 \pm 0.004$ \\
Fe (\%) & $1.84 \pm 0.19$ & $6.61 \pm 1.21$ \\
Mn (\%) & $0.05 \pm 0.008$ & $0.27 \pm 0.08$ \\
Cu (PPM) & $6 \pm 1.35$ & $6 \pm 1.00$ \\
Zn (PPM) & $31 \pm 3.88$ & $24 \pm 4.36$ \\
Cl (PPM) & $69 \pm 8.56$ & $64 \pm 9.27$ \\
\hline
\end{tabular}

\section{Pot Experiment}

The experiment was carried out during Rabi season in 2013-14 (i.e., cold months during November to February) at pot culture facility of CSIR-CSMCRI, Bhavnagar, Gujarat, India $\left(21^{\circ} 44^{\prime} 57.6^{\prime \prime} \mathrm{N}\right.$ latitude, $72^{\circ} 08^{\prime} 39.3^{\prime \prime} \mathrm{E}$ longitude). The experimental soil was sandy clay loam in texture, slightly alkaline (pH: $8.08 \pm 0.03$ ) and non-saline $\left(0.41 \mathrm{dS} \mathrm{m}^{-1}\right.$ ). The soil was low in organic carbon $(0.21 \pm 0.05 \%)$, medium in available $\mathrm{N}\left(0.2 \pm 0.06 \mathrm{~g} \mathrm{~kg}^{-1}\right)$, and high with respect to available $\mathrm{P}$ $\left(0.027 \pm 0.004 \mathrm{~g} \mathrm{~kg}^{-1}\right)$ and available $\mathrm{K}\left(0.30 \pm 0.01 \mathrm{~g} \mathrm{~kg}^{-1}\right)$. The experiment was carried out in pots with $35 \mathrm{~kg}$ soil in each of them. The experiment was laid out in completely randomized design (CRD) comprising of 10 treatments including control (recommended rate of fertilizers through chemical means) and absolute control receiving no nutrients at all. Random number table was used for randomization. Each of the 10 treatments had five replicates, each represented by an individual pot having one plant. The recommended rate of fertilizer (RRF) application was 120:60:40 kg N: $\mathrm{P}_{2} \mathrm{O}_{5}: \mathrm{K}_{2} \mathrm{O}$ hectare ${ }^{-1}$ supplied through urea, single super phosphate (SSP), and MOP, respectively. The test variety employed was F1 hybrid sweet corn, variety: Sugar75 (Syngenta India Ltd.). This variety has very good plant vigor, plant height and is recommended for winter sowing. The maturity of the plant is about 90 days. The variety has long uniform cylindrical cobs, golden yellow kernels, excellent tip filling, high yield, and very sweet taste ( $16 \%$ total soluble sugar).

The treatments $T_{1}$ and $T_{2}$ represented absolute control and RRF, respectively. The treatments $\mathrm{T}_{3}-\mathrm{T}_{6}$ represented substitution of $100,75,50$, and $25 \% \mathrm{~N}$, respectively, through Chlorella derived LMBR. Similarly, treatments $\mathrm{T}_{7}-\mathrm{T}_{10}$ represented substitution of $100,75,50$, and $25 \% \mathrm{~N}$, respectively, through Lyngbya derived LMBR. The remaining proportion of nitrogen (i.e., 0 , 25,50 , and $75 \%$ of $\mathrm{RRF}$ ) in the respective treatments was supplemented through urea fertilizer (containing $46 \% \mathrm{~N}$ ) to accomplish RRF in all the treatments except T1. The phosphorus and potassium inadvertently supplied through biomass were calculated and remaining dose was supplied through SSP and MOP to accomplish the RRF in all the treatments except T1. The biomass and chemical fertilizers were applied to the soil on the day of sowing according to the respective treatments. The crop was harvested at maturity (110th day after sowing).

\section{Recording of Growth Parameters}

Observations on growth parameters [plant height at 20, 40, 60, and 80 days after sowing (DAS), dry matter accumulation (DMA) in leaves, stem, and roots at harvest], grain yield and yield attributes (100-grain weight, number of kernel (grain) rows per cob and number of kernels per row) were recorded. Chlorophyll index of leaves at 20,40,60,80, and 100 DAS was measured using Chlorophyll meter (Opti-Sciences, CCM-200). Photosynthetic rate was measured at 30 and 60 DAS by infrared gas analyzer (LI-6400XT, portable photosynthesis system, LI-COR, USA).

\section{Enzyme Assays}

Enzyme assays were carried at 60 DAS, which corresponded to 10 days pre-tasseling. Any kind of environmental stresses like nutrient or moisture deficiency at this late vegetative growth stage greatly affects the crop performance and therefore this time was chosen to assess any stress response due to the different nutrient management treatments (McWilliams et al., 1999). For carrying out enzyme assays, leaf tissues ( $0.1 \mathrm{~g}$ fresh weight) were collected at 60 DAS and homogenized using a mortar and pestle with liquid nitrogen. The tissue was then extracted with $50 \mathrm{mM}$ Tris extraction buffer ( $\mathrm{pH} 7.5$ ) containing $0.2 \%(\mathrm{w} / \mathrm{v})$ Triton $\mathrm{X}-100,0.1 \mathrm{mM}$ EDTA, $1 \mathrm{mM}$ polymethylsulphonylfluoride, and $2 \mathrm{mM}$ dithiothreitol for glutathione reductase (GR) activity. For ascorbate peroxidase (APX) assay, instead of Tris, $50 \mathrm{mM}$ potassium phosphate buffer ( $\mathrm{pH} 7.0$ ) amended with $2 \mathrm{mM}$ ascorbate was used for extraction. Both the homogenates were vortexed and centrifuged at $20,000 \times \mathrm{g}$ for $30 \mathrm{~min}$ at $4^{\circ} \mathrm{C}$. The supernatants were collected and stored at $-80^{\circ} \mathrm{C}$ until further analysis. Protein content was estimated according to Bradford method (1976) using bovine albumin as a standard and measured using UV-Vis spectrophotometer. The APX (EC 1.11.1.1) and GR (EC 1.6.4.2) activity were measured according to Nakano and Asada (1981) and Edwards et al. (1990), respectively. The concentration of oxidized ascorbate was calculated using an extinction coefficient of $2.8 \mathrm{mM}^{-1} \mathrm{~cm}^{-1}$, while GR activity was calculated using an extinction coefficient of $6.22 \mathrm{M}^{-1} \mathrm{~cm}^{-1}$ for NADPH. One unit of APX is defined as $1 \mathrm{mmol}$ ascorbate oxidized per min per $\mathrm{ml}$ and expressed in units per mg protein. One unit of GR is defined as $1 \mu \mathrm{mol} N A D P H$ oxidized per min per $\mathrm{ml}$ at $25^{\circ} \mathrm{C}$ and expressed in units per $\mathrm{mg}$ protein.

\section{Analytical Methods}

The total nitrogen content in the grain was estimated by standard semi-micro-Kjeldahl method (Thimmaiah, 1999) and expressed in terms of crude protein using a conversion factor of 6.25 (Jones, 1941), while $\mathrm{Na}$ and $\mathrm{K}$ content was determined using flame 
photometry (Flame photometer 128, Systronics, India) according to the method prescribed by Jackson (1973). Phosphorus (P) content in grains was determined by the Vanado-Molybdate yellow method (Jackson, 1973) following wet digestion with $\mathrm{HNO}_{3}-\mathrm{HClO}_{4}(10: 4)$ di-acid mixture. Carbohydrate in grains was estimated by the method of Dubois et al. (1956). Fat content in grains was determined using petroleum ether $\left(\right.$ at $70^{\circ} \mathrm{C}$ ) in a Soxhlet apparatus (AACC, 1987)

The available $\mathrm{N}$ in soil was analyzed by alkaline permanganate method (Subbiah and Asija, 1956). The available $\mathrm{K}$ in soil was extracted by neutral normal ammonium acetate method (Hanway and Heidel, 1952) and available P by sodium bicarbonate as per Olsen et al. (1954) and estimated by flame photometer (Flame photometer 128, Systronics, India) and spectrophotometer (Varian Cary-50 Bio, Varian Inc., USA), respectively. Organic carbon was analyzed according to the method of Walkley and Black (1934).

\section{Statistical Analysis}

The treatments were subjected to statistical analysis by analysis of variance (ANOVA) using InfoStat statistical software V 2012 (Di Rienzo et al., 2011). Post-hoc comparison of means was carried out using Fisher's Least Significant Difference (LSD) at the probability level of $5 \%$ and presented in the tables.

\section{RESULTS}

\section{Effects on Growth Parameters of Maize}

The plant heights recorded in different treatments at 20,40, 60, and 80 DAS are presented in Table 2. The lowest plant height was recorded at all the growth stages under the absolute control treatment where no fertilizer was applied (T1). Compared to $\mathrm{RRF}$, the treatment receiving $\mathrm{N}$ nutrition equally through LMBR from Chlorella and chemical source (T5) gave an initial fillip to the plant height as early as 20 DAS that was maintained significantly till 80 DAS $(P<0.001)$. However, all the treatments employing LMBR from Lyngbya were at par with RRF with respect to plant height at all the days of observations, except T8 at 60 DAS; however, there was no change in the number of nodes due to any of the treatments. Interestingly, the length of the tassels formed by applying either of the LMBRs at any of the substitution rates was markedly higher than that formed under RRF $(P<0.05)$, except that in the treatments employing the lowest level of LMBR from Chlorella and the highest level of that from Lyngbya, where were at par.

Leaf chlorophyll index and net photosynthetic rates recorded at different growth stages are tabulated in Table 3. The chlorophyll index of LMBR treated plants was significantly higher than that of RRF only at 60 DAS $(P<0.001)$ and that also in the T4 and T5 treatments in which 75 and 50\% chemical $\mathrm{N}$ substitution was done through LMBR from Chlorella and in T10 which replaced $25 \%$ of N. All these three treatments were at par. The treatment T10 maintained this advantage even at 100 DAS. T5 and T10, which recorded the highest chlorophyll index at 60 DAS using Chlorella and Lyngbya LMBR, respectively, also recorded the significantly highest net photosynthetic rate $(P<0.001)$ compared to RRF for the respective LMBR at the corresponding time of observation. Both these treatments recorded higher rate of photosynthesis at the early growth stage (30 DAS) as well, however, they were at par with T4 and T6.

The DMA in stem, leaves, and roots and their total at harvest are presented in Table 4. Supplying 75\% of $\mathrm{N}$ through LMBR from Chlorella (T4) resulted in the maximum DMA in stem and roots which were significantly higher over RRF $(P<0.001)$. The leaf dry biomass in this treatment was nevertheless at par with RRF. However, this treatment recorded the significantly highest $(P<0.001)$ total dry matter in the vegetative parts than that in any of the other treatments. There was a marked decline in the DMA in stem and root in all the treatments receiving Lyngbya LMBR, although interestingly, none of them except T10 showed decline in leaf dry weight compared to RRF. This, however, resulted in overall significant decline in the total vegetative DMA, compared to RRF. Further, all the Lyngbya substitution treatments were found at par with respect to total DMA.

TABLE 2 | Effect of different LMBR treatments on plant height and tassel height of maize.

\begin{tabular}{|c|c|c|c|c|c|}
\hline \multirow[t]{2}{*}{ Treatments } & \multicolumn{4}{|c|}{ Plant height (cm) } & \multirow[t]{2}{*}{ Tassel height(cm) } \\
\hline & 20 DAS & 40 DAS & 60 DAS & 80 DAS & \\
\hline T1 & $21.60 \pm 1.14^{d}$ & $68.40 \pm 3.85^{f}$ & $102.60 \pm 4.28^{d}$ & $164.60 \pm 2.07^{\mathrm{e}}$ & $34.20 \pm 2.17^{d}$ \\
\hline T2 & $23.00 \pm 1.00^{C}$ & $76.00 \pm 2.85^{\mathrm{bcde}}$ & $151.80 \pm 7.09^{C}$ & $199.80 \pm 4.92^{\mathrm{bc}}$ & $37.20 \pm 1.92^{\mathrm{cd}}$ \\
\hline T3 & $24.80 \pm 0.84^{a b}$ & $83.40 \pm 6.35^{\mathrm{a}}$ & $167.60 \pm 4.98^{b}$ & $203.40 \pm 7.16^{\mathrm{bc}}$ & $40.60 \pm 1.95^{a b}$ \\
\hline T4 & $23.20 \pm 1.64^{C}$ & $78.40 \pm 3.51^{a b c}$ & $164.40 \pm 3.36^{b}$ & $221.80 \pm 12.01^{a}$ & $40.80 \pm 3.70^{a b}$ \\
\hline T5 & $26.00 \pm 1.00^{a}$ & $80.20 \pm 3.17^{\mathrm{ab}}$ & $177.60 \pm 5.94^{a}$ & $225.40 \pm 8.82^{a}$ & $42.60 \pm 2.97^{a}$ \\
\hline T6 & $23.20 \pm 1.30^{c}$ & $72.60 \pm 5.86^{\text {def }}$ & $153.80 \pm 7.79^{c}$ & $185.40 \pm 7.54^{d}$ & $38.60 \pm 2.97^{b c}$ \\
\hline T7 & $23.40 \pm 1.14^{\mathrm{C}}$ & $76.20 \pm 2.59^{b c d e}$ & $150.20 \pm 6.76^{c}$ & $207.60 \pm 10.55^{b}$ & $39.80 \pm 1.79^{a b c}$ \\
\hline T8 & $24.20 \pm 0.84^{b c}$ & $77.80 \pm 4.40^{\mathrm{bcd}}$ & $163.60 \pm 4.04^{b}$ & $206.80 \pm 5.76^{b}$ & $41.60 \pm 1.14^{a b}$ \\
\hline T9 & $23.80 \pm 0.45^{\mathrm{bc}}$ & $74.30 \pm 3.07^{\text {cde }}$ & $151.40 \pm 5.41^{\mathrm{C}}$ & $194.40 \pm 2.30^{\mathrm{cd}}$ & $41.00 \pm 2.00^{a b}$ \\
\hline T10 & $23.80 \pm 1.10^{\mathrm{bc}}$ & $72.00 \pm 5.00^{e f}$ & $151.80 \pm 3.70^{C}$ & $195.80 \pm 5.63^{C}$ & $41.00 \pm 3.00^{\mathrm{ab}}$ \\
\hline
\end{tabular}

Values followed by different alphabets in columns are significantly different at $p<0.05$ by LSD. 
TABLE 3 | Effect of different LMBR treatments on leaf chlorophyll index and photosynthesis rate of maize.

\begin{tabular}{|c|c|c|c|c|c|c|c|}
\hline \multirow[t]{2}{*}{ Treatments } & \multicolumn{5}{|c|}{ Leaf chlorophyll index } & \multicolumn{2}{|c|}{$\begin{array}{c}\text { Photosynthesis } \\
\left(\mu \text { mole } \mathrm{CO}_{2} / \mathrm{m}^{2} \text { leaf } / \text { day }\right)\end{array}$} \\
\hline & 20 DAS & 40 DAS & 60 DAS & 80 DAS & 100 DAS & 30 DAS & 60 DAS \\
\hline T1 & $22.70 \pm 3.27^{\mathrm{e}}$ & $31.48 \pm 4.30^{\mathrm{C}}$ & $25.38 \pm 2.47^{d}$ & $24.86 \pm 2.93^{d}$ & $19.44 \pm 4.10^{f}$ & $25.45 \pm 1.38^{\mathrm{e}}$ & $16.63 \pm 1.13^{9}$ \\
\hline T2 & $32.90 \pm 3.65^{\mathrm{abc}}$ & $37.08 \pm 3.52^{\mathrm{ab}}$ & $36.88 \pm 3.60^{c}$ & $47.18 \pm 3.56^{a}$ & $34.36 \pm 3.68^{\mathrm{bc}}$ & $34.45 \pm 2.01^{\mathrm{cd}}$ & $26.29 \pm 1.72^{f}$ \\
\hline Т3 & $31.80 \pm 4.45^{b c d}$ & $32.72 \pm 2.22^{\mathrm{bc}}$ & $37.12 \pm 3.17^{\mathrm{C}}$ & $37.72 \pm 4.83^{b c}$ & $27.40 \pm 3.30^{d}$ & $33.32 \pm 0.34^{d}$ & $29.63 \pm 1.38 \mathrm{de}$ \\
\hline T6 & $31.52 \pm 4.69^{\mathrm{bcd}}$ & $36.42 \pm 4.22^{\mathrm{abc}}$ & $43.48 \pm 1.50^{\mathrm{ab}}$ & $41.68 \pm 4.25^{\mathrm{ab}}$ & $35.80 \pm 3.68^{\mathrm{abc}}$ & $41.21 \pm 1.83^{a}$ & $28.61 \pm 2.72^{\mathrm{e}}$ \\
\hline $\mathrm{T7}$ & $28.04 \pm 3.30^{d}$ & $31.44 \pm 5.23^{C}$ & $36.40 \pm 3.63^{C}$ & $37.20 \pm 4.35^{b c}$ & $24.12 \pm 2.74^{\mathrm{de}}$ & $34.55 \pm 3.06^{\mathrm{cd}}$ & $35.65 \pm 1.54^{b}$ \\
\hline T8 & $29.14 \pm 5.17^{\mathrm{cd}}$ & $36.54 \pm 4.86^{\mathrm{abc}}$ & $38.80 \pm 4.82^{b c}$ & $38.58 \pm 6.45^{b c}$ & $20.54 \pm 2.17^{\mathrm{ef}}$ & $33.73 \pm 1.46^{d}$ & $31.51 \pm 0.85^{\mathrm{C}}$ \\
\hline T9 & $28.20 \pm 3.18^{\mathrm{cd}}$ & $31.62 \pm 6.63^{\mathrm{C}}$ & $38.42 \pm 4.73^{b c}$ & $33.26 \pm 5.31^{\mathrm{C}}$ & $27.76 \pm 2.85^{d}$ & $37.35 \pm 3.07^{C}$ & $27.87 \pm 0.19^{\text {ef }}$ \\
\hline T10 & $28.66 \pm 2.78^{\mathrm{cd}}$ & $41.80 \pm 4.22^{\mathrm{a}}$ & $45.58 \pm 4.30^{\mathrm{a}}$ & $40.26 \pm 2.75^{b}$ & $38.52 \pm 3.58^{a}$ & $37.65 \pm 2.82^{b c}$ & $37.83 \pm 0.91^{a}$ \\
\hline
\end{tabular}

Values followed by different alphabets in columns are significantly different at $p<0.05$ by LSD.

TABLE 4 | Effect of different LMBR treatments on dry matter accumulation in above-ground vegetative parts and roots of maize plant.

\begin{tabular}{|c|c|c|c|c|}
\hline Treatments & \multicolumn{4}{|c|}{ Dry matter accumulation (g) } \\
\hline T1 & $82.00 \pm 4.95^{\mathrm{cd}}$ & $79.92 \pm 4.55^{\text {bcde }}$ & $76.64 \pm 8.78^{b c}$ & $238.56 \pm 9.70^{c d}$ \\
\hline T2 & $86.45 \pm 9.02^{\mathrm{C}}$ & $82.27 \pm 3.02^{\mathrm{abc}}$ & $85.84 \pm 7.81^{b}$ & $254.56 \pm 12.71^{b c}$ \\
\hline Т3 & $87.14 \pm 6.73^{b c}$ & $84.18 \pm 11.32^{\mathrm{ab}}$ & $76.92 \pm 5.14^{\mathrm{bc}}$ & $248.24 \pm 18.10^{b c}$ \\
\hline T4 & $109.14 \pm 13.57^{a}$ & $75.57 \pm 3.10^{\text {cde }}$ & $114.74 \pm 13.12^{a}$ & $299.45 \pm 15.10^{a}$ \\
\hline $\mathrm{T7}$ & $81.08 \pm 6.76^{\mathrm{cd}}$ & $81.81 \pm 7.83^{\mathrm{abcd}}$ & $44.003 .66^{\mathrm{d}}$ & $206.89 \pm 8.16^{e}$ \\
\hline T8 & $73.13 \pm 7.16^{d}$ & $75.25 \pm 4.87^{\mathrm{cde}}$ & $52.88 \pm 7.63^{d}$ & $201.27 \pm 14.52^{\mathrm{e}}$ \\
\hline T9 & $73.73 \pm 10.90^{d}$ & $75.83 \pm 3.60^{\text {cde }}$ & $53.24 \pm 4.20^{d}$ & $202.80 \pm 12.88^{\mathrm{e}}$ \\
\hline T10 & $79.25 \pm 6.40^{\mathrm{cd}}$ & $73.28 \pm 5.29^{\mathrm{e}}$ & $47.62 \pm 8.78^{d}$ & $200.15 \pm 17.25^{\mathrm{e}}$ \\
\hline
\end{tabular}

Values followed by different alphabets in columns are significantly different at $p<0.05$ by LSD.

\section{Stress Enzymes}

Preliminary studies on LMBR treated plants also revealed positive results with respect to the stress enzymes studied which was carried out with a view to assess whether the application of the LMBRs on maize plants elicit any stress response. Two key enzymes, namely, ascorbate peroxidase (APX) and glutathione reductase (GR) activities were assayed (Figure 1). It was found that the treatment receiving no external nutrition recorded the highest APX activity, which was significantly higher than that in RRF $(P=0.011)$. Higher APX is suggestive of greater oxidative stress. All the other LMBR treatments had significantly lower activity of this enzyme $(P \leq 0.027)$ than RRF except in T3, which received $\mathrm{N}$ nutrition solely through LMBR of Chlorella. Interestingly, the APX activity decreased with decreasing dose of Chlorella LMBR. However, all the treatments employing LMBR of Lyngbya recorded significantly lower activity $(P<0.001)$ over RRF, which were at par with each other and thus was suggestive of decreased oxidative stress. GR activity was lowest in T1, which was, however, at par to RRF. Among the Chlorella treatments, only T5 recorded significantly higher values of GR activity over $\operatorname{RRF}(P=0.015)$, while the rest were at par. All the Lyngbya treatments except that utilizing LMBR solely as $\mathrm{N}$ source recorded significantly higher GR activity over RRF, the highest being in $\mathrm{T} 9$, which was superior to all the other nine treatments $(P<0.001)$.

\section{Effect on Yield Attributes and Grain Yield}

The length, width, fresh weight as well as the dry weight of the maize cobs with or without the outer husk remained statistically similar in all the LMBR treatments comparable to that in the RRF. Similarly, the same trend was found in number of kernel rows per cob and number of kernels (grains) per row, which determine the total number of grains formed (Table 5). Notably, T8 treatment that substituted $75 \%$ of chemical $\mathrm{N}$ by Lyngbya LMBR had significantly heavier grains compared to RRF $(P=0.008)$, which however was at par with all other LMBR treatments except in T7 where $100 \%$ of $\mathrm{N}$ was supplied by LMBR from Lyngbya. The highest grain weight $\left(65.16 \mathrm{~g} \mathrm{plant}^{-1}\right)$ was measured in T10 where $25 \%$ of the total $\mathrm{N}$ was supplied by Lyngbya derived LMBR and rest by urea, which was closely followed by that $(63.48 \mathrm{~g}$ 
plant $^{-1}$ ) measured in $\mathrm{T} 5$ treatment where $\mathrm{N}$ was supplied to the plants in equal proportion through Chlorella LMBR and urea. However, both these treatments were found at par with other levels of substitutions with LMBRs from either of the algae and were also equivalent to RRF. The yield and its attributes were found the lowest in the absolute control treatment where no external nutrition was supplied.

\section{Effect on Nutritional Quality of Maize}

The carbohydrate, crude protein, and crude fat in maize grains were determined and are presented in Table 6. The carbohydrate content was the maximum where $75 \%$ of $\mathrm{N}$ was supplied through LMBR of Chlorella. This treatment was at par to all the other combinations of Chlorella LMBR, but was significantly superior to RRF $(P=0.018)$ as well as all other Lyngbya treatments $(P \leq 0.021)$. However, all the Lyngbya treated plants were at par with RRF treated ones. There was no change in crude protein content in grains due to either of the two LMBR treatments as

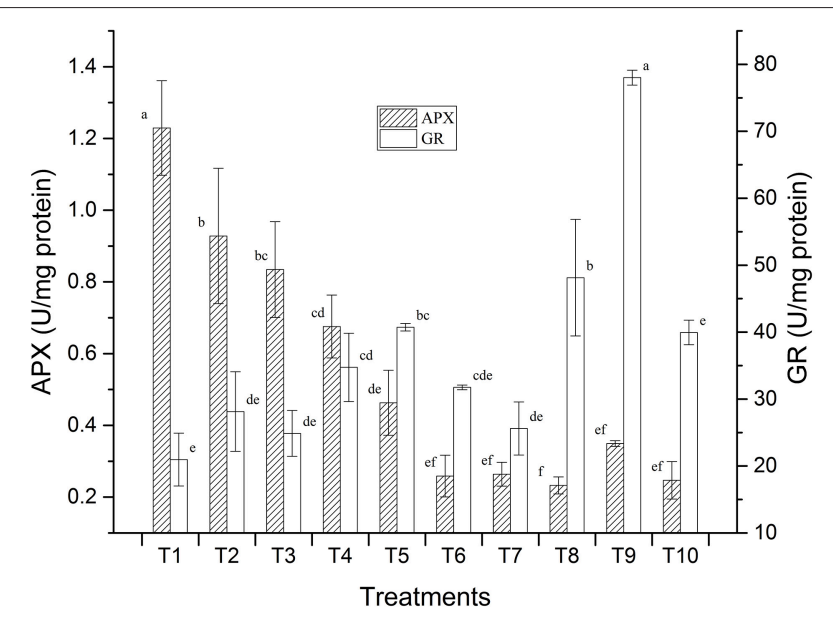

FIGURE 1 | Effect of LMBRs on activities of ascorbate peroxidase and glutathione reductase enzymes of maize at 60 DAS. compared to that in RRF. All the algal biomass treated plants were equivalent with respect to crude fat content, except T3 where $100 \% \mathrm{~N}$ was supplied through Chlorella derived LMBR. With respect to nutritional quality, it was found that there was no change in nitrogen content of the grains due to any of the LMBR treatments when compared to RRF. Compared to RRF, T3, and T10 had the significantly $(P<0.05)$ highest phosphorus content in the Chlorella and Lyngbya derived LMBR treatments, respectively. However, all the LMBR treatments were at par with each other with respect to $P$ content in grains. Compared to RRF, there was significantly $(P<0.001)$ higher potassium uptake in grains in all the LMBR treatments except where $\mathrm{N}$ was entirely supplied through Chlorella derived LMBR. There was a marked increase in sodium as well as potassium content of grains in T10 treatment when compared to that in RRF.

\section{Effects on Physico-chemical Properties of Soil at Harvest}

The changes in physico-chemical properties brought out due to the various treatments are presented in Table 7. It was found that there was no significant difference in $\mathrm{pH}, \mathrm{EC}$, organic carbon, and available $\mathrm{N}$ content in the LMBR treated soil when compared to RRF treated ones. Other than the treatments supplying $100 \%$ (T3) and 75\% (T4) N through Chlorella derived LMBR, all other treatments were at par to RRF with respect to available $P$ content. The two aforesaid treatments were significantly $(P \leq 0$.006) better than all other treatments, but at par with each other. T4 and T5 in case of Chlorella based LMBR and T8 and T10 in case of Lyngbya based LMBR treatments recorded significantly lower available $\mathrm{K}$ in soil at harvest, while all other treatments were at par with RRF.

\section{DISCUSSION}

Among the LMBR from the two algal species, Chlorella derived one apparently was found to be more responsive in improving the plant height as no response was found through LMBR from Lyngbya when compared to RRF (Table 2). Nitrogen nutrition

TABLE 5 | Effect of different LMBR treatments on yield attributes and grain yield of maize.

\begin{tabular}{|c|c|c|c|c|c|}
\hline Treatments & $\begin{array}{c}\text { Grains dry weight } \\
\text { per plant (g) }\end{array}$ & $\begin{array}{c}100 \text { grains dry } \\
\text { weight }(g)\end{array}$ & $\begin{array}{l}\text { Length of kernel } \\
\text { set on cob }(\mathrm{cm})\end{array}$ & $\begin{array}{c}\text { No of kernels } \\
\text { line on cob }\end{array}$ & $\begin{array}{c}\text { No of kernels } \\
\text { per line }\end{array}$ \\
\hline $\mathrm{T} 1$ & $40.99 \pm 6.11^{b}$ & $8.06 \pm 1.81^{\mathrm{C}}$ & $13.73 \pm 2.90^{b}$ & $14.40 \pm 2.61^{\mathrm{b}}$ & $30.47 \pm 0.90^{\mathrm{b}}$ \\
\hline T2 & $61.21 \pm 10.84^{a}$ & $8.60 \pm 0.86^{b c}$ & $18.96 \pm 2.33^{a}$ & $16.00 \pm 0.00^{a b}$ & $32.13 \pm 14.10^{a b}$ \\
\hline T3 & $60.36 \pm 5.26^{a}$ & $9.63 \pm 0.87^{a b}$ & $17.82 \pm 1.69^{a b}$ & $16.80 \pm 1.10^{\mathrm{a}}$ & $40.40 \pm 4.25^{\mathrm{ab}}$ \\
\hline T4 & $59.20 \pm 3.58^{a}$ & $10.05 \pm 1.68^{a b}$ & $17.56 \pm 2.94^{a b}$ & $14.80 \pm 2.28^{a b}$ & $38.80 \pm 8.13^{a b}$ \\
\hline T5 & $63.48 \pm 4.45^{\mathrm{a}}$ & $10.02 \pm 0.74^{a b}$ & $18.25 \pm 1.49^{a}$ & $16.00 \pm 1.41^{\mathrm{ab}}$ & $39.87 \pm 3.20^{a b}$ \\
\hline T6 & $55.70 \pm 11.33^{a}$ & $9.94 \pm 1.38^{\mathrm{ab}}$ & $15.67 \pm 3.46^{a b}$ & $15.60 \pm 0.89^{a b}$ & $34.40 \pm 7.95^{\mathrm{ab}}$ \\
\hline $\mathrm{T} 7$ & $56.29 \pm 13.34^{a}$ & $9.11 \pm 0.86^{b c}$ & $16.61 \pm 2.85^{a b}$ & $16.40 \pm 1.67^{a b}$ & $36.20 \pm 6.30^{a b}$ \\
\hline T8 & $64.93 \pm 3.68^{a}$ & $10.68 \pm 0.72^{a}$ & $18.25 \pm 7.38^{a}$ & $15.60 \pm 0.89^{a b}$ & $32.87 \pm 13.01^{a b}$ \\
\hline T9 & $60.46 \pm 6.92^{a}$ & $10.05 \pm 1.32^{a b}$ & $17.62 \pm 1.81^{a b}$ & $15.60 \pm 1.67^{a b}$ & $39.53 \pm 5.74^{a b}$ \\
\hline T10 & $65.16 \pm 9.45^{a}$ & $9.67 \pm 0.91^{a b}$ & $18.91 \pm 1.96^{\mathrm{a}}$ & $15.60 \pm 1.67^{a b}$ & $41.00 \pm 3.54^{a}$ \\
\hline
\end{tabular}

Values followed by different alphabets in columns are significantly different at $p<0.05$ by LSD. 
TABLE 6 | Effect of different LMBR treatments on nutritional quality of maize.

\begin{tabular}{|c|c|c|c|c|c|c|c|}
\hline Treatments & Carbohydrate (\%) & Crude protein (\%) & Crude fat (\%) & Nitrogen (\%) & Phosphorus (\%) & Potassium (\%) & Sodium (\%) \\
\hline $\mathrm{T} 1$ & $57.19 \pm 2.06^{\mathrm{cd}}$ & $8.73 \pm 1.46^{\mathrm{b}}$ & $10.57 \pm 0.82^{C}$ & $1.40 \pm 0.23^{b}$ & $0.28 \pm 0.06^{a b}$ & $0.51 \pm 0.08^{b c}$ & $0.039 \pm 0.014^{C}$ \\
\hline T2 & $57.97 \pm 3.23^{\mathrm{bcd}}$ & $9.02 \pm 0.91^{a b}$ & $10.63 \pm 1.30^{\mathrm{bc}}$ & $1.44 \pm 0.15^{a b}$ & $0.18 \pm 0.05^{b}$ & $0.33 \pm 0.02^{d}$ & $0.043 \pm 0.010^{c}$ \\
\hline T3 & $60.68 \pm 3.67^{a b c}$ & $11.27 \pm 3.76^{\mathrm{a}}$ & $11.82 \pm 0.98^{a}$ & $1.80 \pm 0.60^{a}$ & $0.39 \pm 0.41^{a}$ & $0.27 \pm 0.10^{d}$ & $0.046 \pm 0.012^{c}$ \\
\hline T4 & $63.21 \pm 3.59^{a}$ & $9.85 \pm 0.87^{a b}$ & $11.26 \pm 0.78^{a b c}$ & $1.58 \pm 0.14^{a b}$ & $0.28 \pm 0.03^{a b}$ & $0.44 \pm 0.09^{c}$ & $0.048 \pm 0.025^{b c}$ \\
\hline T5 & $61.49 \pm 4.78^{a b}$ & $9.68 \pm 1.20^{\mathrm{ab}}$ & $11.26 \pm 0.78^{a b c}$ & $1.55 \pm 0.19^{a b}$ & $0.28 \pm 0.05^{a b}$ & $0.56 \pm 0.04^{a b}$ & $0.044 \pm 0.004^{c}$ \\
\hline T6 & $60.47 \pm 1.54^{a b c}$ & $9.62 \pm 1.02^{a b}$ & $11.30 \pm 0.97^{a b c}$ & $1.54 \pm 0.16^{a b}$ & $0.35 \pm 0.12^{a b}$ & $0.58 \pm 0.06^{a b}$ & $0.047 \pm 0.004^{b c}$ \\
\hline T7 & $58.08 \pm 3.45^{\mathrm{bcd}}$ & $9.59 \pm 2.36^{a b}$ & $11.05 \pm 0.85^{a b c}$ & $1.53 \pm 0.38^{a b}$ & $0.36 \pm 0.14^{a b}$ & $0.58 \pm 0.11^{a b}$ & $0.044 \pm 0.005^{c}$ \\
\hline T8 & $57.02 \pm 4.06^{\mathrm{cd}}$ & $9.31 \pm 0.75^{a b}$ & $11.75 \pm 0.59^{a b}$ & $1.49 \pm 0.12^{a b}$ & $0.30 \pm 0.06^{a b}$ & $0.52 \pm 0.02^{\mathrm{abc}}$ & $0.042 \pm 0.006^{c}$ \\
\hline T9 & $57.24 \pm 1.84^{\mathrm{bcd}}$ & $9.71 \pm 1.82^{a b}$ & $11.53 \pm 0.90^{\mathrm{abc}}$ & $1.55 \pm 0.29^{a b}$ & $0.28 \pm 0.05^{a b}$ & $0.52 \pm 0.02^{\mathrm{abc}}$ & $0.078 \pm 0.013^{a}$ \\
\hline T10 & $53.92 \pm 3.90^{d}$ & $10.28 \pm 2.47^{\mathrm{ab}}$ & $11.07 \pm 0.75^{a b c}$ & $1.64 \pm 0.40^{a b}$ & $0.41 \pm 0.22^{a}$ & $0.62 \pm 0.16^{a}$ & $0.062 \pm 0.004^{b}$ \\
\hline
\end{tabular}

Values followed by different alphabets in columns are significantly different at $p<0.05$ by LSD.

TABLE 7 | Effect of different LMBR treatments on physico-chemical properties of soil at harvest.

\begin{tabular}{|c|c|c|c|c|c|c|c|}
\hline Treatments & Moisture (\%) & $\mathrm{pH}$ & $\mathrm{EC}(\mathrm{dS} / \mathrm{m})$ & Available N (g/kg) & Available P (g/kg) & Available K (g/kg) & Organic carbon (\%) \\
\hline T1 & $15.89 \pm 1.65^{a}$ & $7.69 \pm 0.24^{a}$ & $1.14 \pm 0.12^{b}$ & $0.13 \pm 0.03^{b}$ & $0.03 \pm 0.01^{b c}$ & $0.39 \pm 0.06^{a}$ & $0.20 \pm 0.03^{a}$ \\
\hline T2 & $13.24 \pm 2.30^{b}$ & $7.47 \pm 0.17^{\mathrm{a}}$ & $1.29 \pm 0.24^{\mathrm{ab}}$ & $0.12 \pm 0.02^{b}$ & $0.05 \pm 0.02^{b}$ & $0.40 \pm 0.06^{a}$ & $0.15 \pm 0.04^{b}$ \\
\hline T3 & $13.68 \pm 1.82^{a b}$ & $7.58 \pm 0.15^{\mathrm{a}}$ & $1.56 \pm 0.27^{\mathrm{a}}$ & $0.13 \pm 0.05^{b}$ & $0.08 \pm 0.03^{a}$ & $0.39 \pm 0.11^{a}$ & $0.20 \pm 0.03^{a b}$ \\
\hline T4 & $13.78 \pm 0.95^{a b}$ & $7.59 \pm 0.22^{a}$ & $1.32 \pm 0.24^{a b}$ & $0.13 \pm 0.04^{b}$ & $0.08 \pm 0.02^{a}$ & $0.29 \pm 0.01^{b}$ & $0.18 \pm 0.03^{a b}$ \\
\hline T5 & $15.00 \pm 2.43^{a b}$ & $7.66 \pm 0.42^{a}$ & $1.19 \pm 0.20^{b}$ & $0.15 \pm 0.04^{b}$ & $0.03 \pm 0.02^{b c}$ & $0.29 \pm 0.05^{b}$ & $0.19 \pm 0.03^{a b}$ \\
\hline T6 & $13.83 \pm 3.75^{\mathrm{ab}}$ & $7.63 \pm 0.21^{a}$ & $1.25 \pm 0.10^{b}$ & $0.15 \pm 0.03^{b}$ & $0.03 \pm 0.01^{b c}$ & $0.34 \pm 0.08^{\mathrm{ab}}$ & $0.19 \pm 0.02^{a b}$ \\
\hline T7 & $13.64 \pm 1.43^{\mathrm{ab}}$ & $7.63 \pm 0.26^{a}$ & $1.24 \pm 0.21^{b}$ & $0.16 \pm 0.10^{b}$ & $0.02 \pm 0.01^{b}$ & $0.31 \pm 0.09^{a b}$ & $0.16 \pm 0.06^{a b}$ \\
\hline T8 & $15.37 \pm 0.81^{a b}$ & $7.79 \pm 0.21^{a}$ & $1.32 \pm 0.38^{a b}$ & $0.41 \pm 0.24^{a}$ & $0.03 \pm 0.01^{b}$ & $0.36 \pm 0.08^{b}$ & $0.18 \pm 0.02^{a b}$ \\
\hline T9 & $13.44 \pm 1.39^{a b}$ & $7.76 \pm 0.23^{a}$ & $1.29 \pm 0.22^{\mathrm{ab}}$ & $0.14 \pm 0.05^{b}$ & $0.02 \pm 0.00^{b}$ & $0.34 \pm 0.08^{\mathrm{ab}}$ & $0.17 \pm 0.05^{\mathrm{ab}}$ \\
\hline T10 & $14.50 \pm 1.22^{\mathrm{ab}}$ & $7.76 \pm 0.39^{a}$ & $1.30 \pm 0.27^{\mathrm{ab}}$ & $0.26 \pm 0.18^{b}$ & $0.04 \pm 0.02^{b c}$ & $0.29 \pm 0.04^{b}$ & $0.19 \pm 0.03^{a b}$ \\
\hline
\end{tabular}

Values followed by different alphabets in columns are significantly different at $p<0.05$ by LSD.

derived equally from both organic and chemical sources seemed to be the best balanced dose that sustained higher plant height relative to RRF starting from as early as 20 DAS till 80 DAS. It was observed that substitution of $100-50 \%$ of total N (T3-T5) through Chlorella LMBR treatments maintained the plant height at par with RRF or was even higher until 60 DAS. However, lowest rate of substitution in T6 $(25 \%)$ brought about a diminution suggesting the role of the algal biomass toward sustained supply of nutrients or other active factors to the plants.

With respect to total DMA in the above ground vegetative parts and roots, contrasting results were found between LMBR from Chlorella and Lyngbya (Table 4). Whereas, 100 to 50\% $\mathrm{N}$ substitutions through Chlorella biomass resulted in higher or equivalent DMA, similar levels of substitution by Lyngbya resulted in significant decrease when compared to that in RRF, suggesting the presence of one or more factor in the latter that are responsible for diminution of growth. Substitution of $25 \% \mathrm{~N}$ through either of the LMBR invariably brought a significant decrease in the aforesaid total DMA, connoting the requirement of Chlorella in higher amounts and confirming the retardant activity of LMBR from Lyngbya even at lower doses of substitution. The differential response between the two algal LMBRs might be on the account of their composition, which thus needs to be fully unraveled. This may indicate the presence of some toxic ingredients in Lyngbya species that negatively affect the plant growth. There are reports of toxicity of the microalgal extracts affecting the growth of plants (Romanowska-Duda and Tarczyñska, 2002) thus validating the argument (Grzesik and Romanowska-Duda, 2015) that untested algal residues should not be employed for treatment on plants.

Interestingly, there was no decrease in DMA in leaf due to the Lyngbya treatments except that in T10 where least level of substitution (25\%) was done, which was also equivalent to all the other Lyngbya treatments. T4 fared the best among all the treatments for total DMA which could be primarily attributed to increase in stem and root biomass, while T5 formed the highest leaf biomass, which was although similar to that in RRF. The highest plant height and leaf biomass found in the LMBR treatment using biomass of Chlorella in equal proportion as chemical N (T5) at 60 DAS can be well-corroborated by the leaf chlorophyll index and net photosynthetic rate recorded during this time (Table 3), which were found to be the highest among all the Chlorella treatments and significantly superior to RRF. Notably, in spite of lower DMA in the vegetative biomass in all the Lyngbya treatments, compared to RRF, there was no significant decrease in net photosynthetic rate at the leaf level, as evident from its values recorded at 30 and 60 DAS (Table 3). Rather, it was significantly higher than all other treatments at 
60 DAS. This treatment also showed the best chlorophyll index among all the Lyngbya LMBR treatments at all the times and was significantly higher than RRF before (60 DAS) as well as after tasseling stage (100 DAS) of the plant. Grzesik and Romanowska-Duda (2015) also similarly reported intensification of several metabolic processes such as net photosynthesis and other gas exchange parameters, stability of cytomembranes which eventually led to enhanced shoot and root dry weight of willow plants by application of sonicated biomass of two species of Cyanobacteria (Microcystis sp. and Anabaena sp.) and one green algae (Chlorella sp.).

Thus, the observations recorded on plant height, leaf chlorophyll index, net photosynthetic rate and above ground vegetative DMA in the treatments using LMBR from Chlorella suggest that any level of substitution resulted in either maintaining the growth parameters or improving it in some of the treatments. This possibly explained for the equivalent grain yield obtained from all the Chlorella derived LMBR treatments, compared to RRF. Besides, microalgae, which itself is photosynthetic, have all the plant essential elements in its biomass (Table 1) which are left in the residue after oil extraction and upon decomposition are available to the plants fertilized with it. Even though there was a detrimental effect on the total DMA by using LMBR from Lyngbya (Table 4), the maintenance of similar or higher photosynthetic rate leading to attainment of similar leaf biomass might have resulted in better partitioning of photosynthates to the grains, thus explaining for the similar grain yields despite the mentioned limitations. Evidently, even though the grain yield of maize was found similar to RRF in all the LMBR treatments, irrespective of the species of algae it was derived from, there were differences in the quality of grains due to the different treatments (Table 6). Whereas, there was no change in the protein content, T4 was nutritionally superior in terms of carbohydrate content, while T3 was superior with respect to fat and phosphorus content when compared over RRF. T10 was superior in terms of $\mathrm{P}, \mathrm{K}$ as well as $\mathrm{Na}$ content when compared to RRF.

Strikingly, it was found that all the LMBR treatments except T3 had marked enhancement in the potassium content. Potassium has a prominent role in imparting stress tolerance in plants (Zörb et al., 2014). Another notable observation was that all the LMBR treatments exhibited a significantly longer tassel compared to that in RRF except that in T6 and T7, which were also numerically superior (Table 1). A longer tassel has been reported to be desirable under stress environment to ensure sufficient and extended pollen availability (Sofi, 2007). Even though the plants in the present experiment were not subjected to any specific stress, nevertheless, plants do experience biotic and abiotic stress, even at different times of the day during its growth and reproductive phase when grown under uncontrolled conditions (Layek et al., 2015). Such stress may be due to temperature extremities during day or night, incipient wilting during mid-day, variation in soil moisture, pest attack, etc., all of which could induce instantaneous production of reactive oxygen species (ROS). The results obtained from our studies on ROS scavengers like APX suggests that LMBRs may also be important for imparting tolerance under environmental stress and may be explored in the future on this aspect. The presence of bioelicitors in the LMBRs may also be explored which can perhaps trigger plant defense pathways in response to biotic and abiotic stresses. Such elicitors have been reported in other green algae like Ulva lactuca (Grzesik and Romanowska-Duda, 2015).

Evidently, no detrimental effect was found in the $\mathrm{pH}$ and EC of the soil due to the various LMBR treatments (Table 7). Although, there was no change in organic carbon content of soil, continuous application of the carbon rich LMBR may have a significant beneficial effect in the long run. The treatments employing $100 \%$ (T3) and $75 \%$ (T4) $\mathrm{N}$ through Chlorella-derived LMBR had a striking effect in improving available phosphorus in soil which may be ascribed to the improved microbial and associated biochemical activity of such carbonaceous materials (Anand et al., 2015). Interestingly, T3 also had the highest $\mathrm{P}$ content in the grains, all of which connote toward greater mineralization of soil phosphorus and also the higher mobilization of phosphorus to the grains of soil, which needs to be investigated in future. Grzesik and RomanowskaDuda (2014) recently reported that application of microalgal residues to corn plants significantly enhanced the activity of phosphatase enzyme, which is responsible for distribution of $\mathrm{P}$ in plants. The use of LMBR may also confer another advantage by preventing the loss of soil nutrients by way of leaching or volatilization, thus being a sustainable release nutrient source. Mulbry et al. (2005) reported that only $3 \%$ of algal $\mathrm{N}$ was present as plant available $\mathrm{N}$ in soil at the time of application of dried algal biomass (day 0 ). Similar to our studies, they also found that dried algal biomass was equivalent to fertilizer in supplying $\mathrm{N}$ and $\mathrm{P}$ to cucumber and corn. It was further conjectured that $\mathrm{NH}_{3}$ volatilization would not occur by use of dried algal biomass as manure in contrast to the use of chemical fertilizers.

Chemical solvent extraction is the most common method to effectively extract lipids from algae cells, but use of solvents like n-hexane and electric power, makes the cost of oil production high. In our case, LMBR was produced on a smaller scale for the purpose of conducting pot experiments. Other methods like wet extraction (Reddy et al., 2014), supercritical fluid technologies using $\mathrm{CO}_{2}$ (Halim et al., 2011), milking extraction methods (Kleinegris et al., 2010) are emerging as newer technologies for lipid extraction that would considerably economize on the cost and energy requirement. Even though efforts to extract the microalgal lipids and recover the solvent used has been recently demonstrated by using solar driven solvent extractor (Ghosh et al., 2013), nevertheless, it is extremely important that the algal residue obtained after extraction of the main product (oil) should be used in a biorefinery approach, which was the primary objective of the study. We found that the LMBRs deserved proper exploitation as fertilizer substitute as they are rich in plant nutrients. Considering the state of the art of algal production and post-harvest technology, the current production of biofuel from microalgae is technically feasible, but its economic feasibility is still a major challenge (Chiaramonti et al., 2015). The results of the present experiment applying the biorefinery concept to valorize the LMBR as a plant nutrient source is one of the ways to achieve economic sustainability of algal biofuel. 
In view of promising results and due to the limited information available in the literature on this aspect of worldwide interest, further studies are required to evaluate the effect of the use of LMBRs on crop plants over the long term and understand the mechanism of action as well. The effects of LMBRs on soil microbial and biochemical properties, which have bearing on the nutrient cycle, also need to be studied in the future. Other active ingredients or anti-nutrients present in LMBRs also need to be characterized.

\section{CONCLUSION}

In the present study, nitrogen-rich LMBRs of two microalgal species, namely, Chlorella and Lyngbya were utilized to substitute for the chemical nitrogen fertilizer requirement of maize plants in different proportions viz., 100, 75, 50, and 25\%. The grain yield obtained using either of the LMBRs were equivalent to that under treatment employing RRF solely through chemical fertilizers. Even though LMBR of Lyngbya resulted in diminution of the stem and root biomass, there was no reduction observed in the formation of leaf biomass and photosynthetic rate as a result of which the translocation of assimilates from the source to sink was maintained and similar grain yields to that in RRF were obtained using it. Substitution of $75 \%$ of the total chemical $\mathrm{N}$ through Chlorella LMBR (T4) resulted in the highest DMA in above-ground vegetative biomass and roots and this treatment also recorded the highest grain carbohydrate content, all of which were significantly superior to that in RRF. Among the Lyngbya treatments, substitution at $25 \%$ level (T10) was found to be the best in terms of grain yield production as well as phosphorus

\section{REFERENCES}

AACC (1987). Approved Methods of the AACC. St Paul, MN: American Association of Cereal Chemists Inc.

Anand, K. G. V., Kubavat, D., Trivedi, K., Agarwal, P. K., Wheeler, C., and Ghosh, A. (2015). Long-term application of Jatropha press cake promotes seed yield by enhanced soil organic carbon accumulation, microbial biomass and enzymatic activities in soils of semi-arid tropical wastelands. Eur. J. Soil Biol. 69, 57-65. doi: 10.1016/j.ejsobi.2015.05.005

Bradford, M. M. (1976). A rapid and sensitive method for the quantitation of microgram quantities of protein utilizing the principle of protein-dye binding. Anal. Biochem. 72, 248-254. doi: 10.1016/0003-2697(76)90527-3

Bryant, H. L., Gogichaishvili, I., Anderson, D., Richardson, J. W., Sawyer, J., Wickersham, T., et al. (2012). The value of post-extracted algae residue. Algal Res. 1, 185-193. doi: 10.1016/j.algal.2012.06.001

Chiaramonti, D., Tredici, M. R., Prussi, M., and Biondi, N. (2015). Algae Biofuels. Handbook of Clean Energy Systems. New Jersey: John Wiley \& Sons, Ltd.

Chisti, Y. (2007). Biodiesel from microalgae. Biotechnol. Adv. 25, 294-306. doi: 10.1016/j.biotechadv.2007.02.001

Di Rienzo, J. A., Casanoves, F., Balzarini, M. G., Gonzalez, L., Tablada, M., and Robledo, Y. C. (2011). InfoStat Versión 2011. Grupo InfoStat, FCA. Universidad Nacional de Córdoba, Argentina. Available online at: http://www. infostat.com.ar

Dubois, M., Gilles, K. A., Hamilton, J. K., Rebers, P. A., and Smith, F. (1956). Colorimetric method for determination of sugars and related substances. Anal. Chem. 28, 350-356. doi: 10.1021/ac60111a017

Edwards, E. A., Rawsthorne, S., and Mullineaux, P. M. (1990). Subcellular distribution of multiple forms of glutathione reductase in leaves of pea (Pisum sativum L.). Planta 180, 278-284. doi: 10.1007/BF00194008 and potassium content in grains, while carbohydrate, protein as well as fat content were found at par with RRF. Decreased APX enzyme activity, indicative of lower plant stress was also apparent in most of the LMBR treatments. There was also no detrimental effect of the various LMBR treatments on soil properties. Based on the results, it is concluded that both of the LMBRs can substitute, wholly or partially, the chemical nitrogen fertilizer without affecting the yield and quality of the maize crop, thereby reducing the usage of chemical fertilizers in agriculture and simultaneously making gainful use of the LMBRs generated during biodiesel preparation. The results obtained from the present study thus helps to valorize the LMBR in the commodity markets, thereby advancing toward the economic sustainability of algae production for biofuels.

\section{ACKNOWLEDGMENTS}

This manuscript bears the number CSIR-CSMCRI - 129/2015. We acknowledge CSIR for providing the support for this work through MoES-NMITLI (TLP 0096). We gratefully thank Dr. Ruma Pal and Mr. Gour Gopal Satpati for providing Lyngbya sp. biomass. The authors would like to acknowledge Mr. Chhaganbhai Jambucha for help in pot experiment. The authors also acknowledge Dr. Parimal Paul, DC, ADCIF, CSIRCSMCRI, Bhavnagar for providing the instrumentation facility. $\mathrm{RM}, \mathrm{KC}, \mathrm{TG}, \mathrm{KT}$, IP, and DK would like to acknowledge CSIR, CSC 0203 and CSC 0105 for awarding fellowship and AcSIR for Ph.D. enrollment. We also thank Dr. P. K. Ghosh, Dr. Arvind Kumar and Dr. P. K. Agarwal for their generous support and helpful advice.

Gao, M. T., Shimamura, T., Ishida, N., and Takahashi, H. (2012). Investigation of utilization of the algal biomass residue after oil extraction to lower the total production cost of biodiesel. J. Biosci. Bioeng. 114, 330-333. doi: 10.1016/j.jbiosc.2012.04.002

Ghosh, A. (2012). Indra's net and the midas touch: living sustainably in a connected world. Int. J. Environ. Stud. 69, 859-863. doi: 10.1080/00207233.2012.705079

Ghosh, A. (2014). Plane truth: aviation's real impact on people and the environment. Int. J. Environ. Stud. 71, 888-898. doi: 10.1080/00207233.2014.964063

Ghosh, A., Chaudhary, D. R., Reddy, M. P., Rao, S. N., Chikara, J., Pandya, J. B., et al. (2007). Prospects for Jatropha methyl ester (biodiesel) in India. Int. J. Environ. Stud. 64, 659-674. doi: 10.1080/00207230701766499

Ghosh, P. K., Mishra, S., Maiti, S., Paliwal, C., Mishra, S. K., Ghosh, T., et al. (2013). Solar Driven Solvent Extractor and Process for Extraction of Microalgal Lipids Using the Same. U.S. Patent No 14/389,824. Alexandria, VA: USPTO.

Grzesik, M., and Romanowska-Duda, Z. (2014). Improvements in germination, growth, and metabolic activity of corn seedlings by grain conditioning and root application with cyanobacteria and microalgae. Pol. J. Environ. Stud. 23, 1147-1153. Available online at: http://www.pjoes.com/pdf/23.4/Pol.J.Environ. Stud.Vol.23.No.4.1147-1153.pdf

Grzesik, M., and Romanowska-Duda, Z. (2015). Ability of cyanobacteria and green algae to improve metabolic activity and development of willow plants. Pol. J. Environ. Stud. 24, 1003-1012. doi: 10.15244/pjoes/ 34667

Halim, R., Gladman, B., Danquah, M. K., and Webley, P. A. (2011). Oil extraction from microalgae for biodiesel production. Bioresour. Technol. 102, 178-185. doi: 10.1016/j.biortech.2010.06.136

Hanway, J. J., and Heidel, H. (1952). Soil analysis methods as used in Iowa state college soil testing laboratory. Iowa Agric. 57, 1-31. 
Jackson, M. L. (1973). Soil Chemical Analysis. New Delhi: Prentice Hall of India Pvt. Ltd.

Jones, D. B. (1941). Factors for Converting Percentages of Nitrogen in Foods and Feeds into Percentages of Proteins. Washington, DC: US Department of Agriculture.

Kleinegris, D. M., Janssen, M., Brandenburg, W. A., and Wijffels, R. H. (2010). The selectivity of milking of Dunaliella salina. Marine Biotechnol. 12, 14-23. doi: 10.1007/s10126-009-9195-0

Layek, J., Das, A., Ramkrushna, G. I., Trivedi, K., Yesuraj, D., Chandramohan, M., et al. (2015). Seaweed sap: a sustainable way to improve productivity of maize in North-East India. Int. J. Environ. Stud. 72, 305-315. doi: 10.1080/00207233.2015.1010855

Mata, T. M., Martins, A. A., and Caetano, N. S. (2010). Microalgae for biodiesel production and other applications: a review. Renew. Sustain. Energy Rev. 14, 217-232. doi: 10.1016/j.rser.2009.07.020

Maurya, R., Ghosh, T., Paliwal, C., Shrivastav, A., Chokshi, K., Pancha, I., et al. (2014). Biosorption of methylene blue by de-oiled algal biomass: equilibrium, kinetics and artificial neural network modelling. PLOS ONE 9:e109545. doi: 10.1371/journal.pone.0109545

McWilliams, D. A., Berglund, D. R., and Endres, G. J. (1999). Corn Growth and Management Quick Guide. North Dakota State University and University of Minnesota. A-1173.

Metting, B., and Rayburn, W. R. (1983). The influence of a microalgal conditioner on selected Washington soils: an empirical study. Soil Sci. Soc. Am. J. 47, 682-685. doi: 10.2136/sssaj1983.03615995004700040015x

Mishra, S. C. P., Ghosh, P. K., Gandhi, M. R., Bhattacharya, S., Maiti, S., Upadhyay, S. C., et al. (2012). Engine Worthy Fatty Acid Methyl Ester (biodiesel) from Naturally Occuring Marine Microalgal Mats and Marine Microalgae Cultured in Open Salt Pans Together with Value Addition of Co-products. U.S. Patent No US20140099684 A1. Alexandria, VA: USPTO.

Mulbry, W., Westhead, E. K., Pizarro, C., and Sikora, L. (2005). Recycling of manure nutrients: use of algal biomass from dairy manure treatment as a slow release fertilizer. Bioresour. Technol. 96, 451-458. doi: 10.1016/j.biortech.2004.05.026

Nakano, Y., and Asada, K. (1981). Hydrogen peroxide is scavenged by ascorbatespecific peroxidase in spinach chloroplasts. Plant Cell Physiol. 22, 867-880.

Olsen, S. R., Cole, C. V., Watanabe, F. S., and Dean, L. A. (1954). Estimation of available phosphorus in soils by extraction with sodium bicarbonate. USDA Circular, 939.

Pfromm, P. H., Amanor-Boadu, V., and Nelson, R. (2011). Sustainability of algae derived biodiesel: a mass balance approach. Bioresour. Technol. 102, 1185-1193. doi: 10.1016/j.biortech.2010.09.050

Rashid, N., Rehman, M. S. U., and Han, J. I. (2013). Recycling and reuse of spent microalgal biomass for sustainable biofuels. Biochem. Eng. J. 75, 101-107. doi: 10.1016/j.bej.2013.04.001

Reddy, H. K., Muppaneni, T., Patil, P. D., Ponnusamy, S., Cooke, P., Schaub, T., et al. (2014). Direct conversion of wet algae to crude biodiesel under supercritical ethanol conditions. Fuel 115, 720-726. doi: 10.1016/j.fuel.2013.07.090

Rodolfi, L., Chini Zittelli, G., Bassi, N., Padovani, G., Biondi, N., Bonini, G., et al. (2009). Microalgae for oil: strain selection, induction of lipid synthesis and outdoor mass cultivation in a low-cost photobioreactor. Biotechnol. Bioeng. 102, 100-112. doi: 10.1002/bit.22033

Romanowska-Duda, Z., and Tarczyñska, M. (2002). The influence of microcystin-LR and hepatotoxic cyanobacterial extract on the water plant
Spirodela oligorrhiza. Environ. Toxicol. 17, 434-440. doi: 10.1002/tox. 10076

Scott, S. A., Davey, M. P., Dennis, J. S., Horst, I., Howe, C. J., Lea-Smith, D. J., et al. (2010). Biodiesel from algae: challenges and prospects. Curr. Opin. Biotechnol. 21, 277-286. doi: 10.1016/j.copbio.2010.03.005

Singh, S., Singh, M. K., Pal, S. K., Trivedi, K., Yesuraj, D., Singh, C. S., et al. (2015). Sustainable enhancement in yield and quality of rain-fed maize through Gracilaria edulis and Kappaphycus alvarezii seaweed sap. J. Appl. Phycol. doi: 10.1007/s10811-015-0680-8. [Epub ahead of print].

Sofi, P. A. (2007). Genetic analysis of tassel and ear characters in maize (Zea mays L.) using triple test cross. Asian J. Plant Sci. 6, 881-883. doi: 10.3923/ajps.2007.881.883

Studt, T. (2010). Algae promise biofuel solutions. INFORM 21, 319-324.

Subbiah, B. V., and Asija, G. L. (1956). A rapid procedure for the estimation of available nitrogen in soil. Curr. Sci. 25, 259-260.

Thimmaiah, S. K. (1999). Standard Methods of Biochemical Analysis. New Delhi: Kalyani Publishers.

Toth, S. J., Prince, A. I., Wallace, A., and Mikkelsen, D. S. (1948). Rapid quantitative determination of eight mineral elements in plant tissues by a systematic procedure involving use of a flame photometer. Soil Sci. 66, 459-466. doi: 10.1097/00010694-194812000-00006

Vance, C. P. (2001). Symbiotic nitrogen fixation and phosphorus acquisition. Plant nutrition in a world of declining renewable resources. Plant Physiol. 127, 390-397. doi: $10.1104 /$ pp. 010331

van Wychen, S., and Laurens, L. M. L. (2013). Determination of Total Solids and Ash in Algal Biomass. Laboratory Analytical Procedure. Colorado: Technical Report. NREL/TP-5100-60956

Verdelho, V. (2013). "European projects and ventures for large-scale algae biomass production" in 1st LIMBAC (Lisbon).

Walkley, A. J., and Black, C. A. (1934). An examination of the method for determining soil organic matter and a proposed modification of the chromic acid titration method. Soil Sci. 37, 29-38. doi: 10.1097/00010694-19340100000003

Zittelli, G. C., Biondi, N., Rodolfi, L., and Tredici, M. R. (2013b). "Photobioreactors for mass production of microalgae," in Handbook of Microalgal Culture. Applied Phycology and Biotechnology, 2nd Edn., eds A. Richmond and Q. Hu (Chichester: Wiley Blackwell), 225-266.

Zittelli, G. C., Rodolfi, L., Bassi, N., Biondi, N., and Tredici, M. R. (2013a). "Photobioreactors for microalgal biofuel production," in Algae for Biofuels and Energy, eds M. A. Borowitzka and N. R. Moheimani ( Dordrecht: Springer), $115-132$.

Zörb, C., Senbayram, M., and Peiter, E. (2014). Potassium in agriculture-status and perspectives. J. Plant physiol. 171, 656-669. doi: 10.1016/j.jplph.2013.08.008

Conflict of Interest Statement: The authors declare that the research was conducted in the absence of any commercial or financial relationships that could be construed as a potential conflict of interest.

Copyright (๑) 2016 Maurya, Chokshi, Ghosh, Trivedi, Pancha, Kubavat, Mishra and Ghosh. This is an open-access article distributed under the terms of the Creative Commons Attribution License (CC BY). The use, distribution or reproduction in other forums is permitted, provided the original author(s) or licensor are credited and that the original publication in this journal is cited, in accordance with accepted academic practice. No use, distribution or reproduction is permitted which does not comply with these terms. 